\title{
Inhibition of Hazara nairovirus replication by small interfering RNAs and their combination with ribavirin
}

\author{
Olivier Flusin ${ }^{1 *}$, Solenne Vigne ${ }^{1,3}$, Christophe N Peyrefitte ${ }^{1}$, Michèle Bouloy ${ }^{2}$, Jean-Marc Crance ${ }^{1}$ and Frédéric Iseni ${ }^{1}$
}

\begin{abstract}
Background: The genus Nairovirus in the family Bunyaviridae contains 34 tick-borne viruses classified into seven serogroups. Hazara virus (HAZV) belongs to the Crimean-Congo hemorrhagic fever (CCHF) serogroup that also includes CCHF virus (CCHFV) a major pathogen for humans. HAZV is an interesting model to study CCHFV due to a close serological and phylogenetical relationship and a classification which allows handling in a BSL2 laboratory. Nairoviruses are characterized by a tripartite negative-sense single stranded RNA genome (named L, M and S segments) that encode the RNA polymerase, the Gn-Gc glycoproteins and the nucleoprotein (NP), respectively. Currently, there are neither vaccines nor effective therapies for the treatment of any bunyavirus infection in humans. In this study we report, for the first time, the use of RNA interference (RNAi) as an approach to inhibit nairovirus replication.
\end{abstract}

Results: Chemically synthesized siRNAs were designed to target the mRNA produced by the three genomic segments. We first demonstrated that the siRNAs targeting the NP mRNA displayed a stronger antiviral effect than those complementary to the $L$ and $M$ transcripts in A549 cells. We further characterized the two most efficient siRNAs showing, that the induced inhibition is specific and associated with a decrease in NP synthesis during HAZV infection. Furthermore, both siRNAs depicted an antiviral activity when used before and after HAZV infection. We next showed that HAZV was sensitive to ribavirin which is also known to inhibit CCHFV. Finally, we demonstrated the additive or synergistic antiviral effect of siRNAs used in combination with ribavirin.

Conclusions: Our study highlights the interest of using RNAi (alone or in combination with ribavirin) to treat nairovirus infection. This approach has to be considered for the development of future antiviral compounds targeting CCHFV, the most pathogenic nairovirus.

\section{Background}

Hazara virus (HAZV) is a member of the genus Nairovirus of the family Bunyaviridae which also includes Orthobunyavirus, Hantavirus, Phlebovirus and Tospovirus. Nairovirus comprises 34 tick-borne viruses classified into seven serogroups. The main representative serogroups are the Nairobi sheep disease group containing Nairobi sheep disease virus (NSDV) and Dugbe virus and the Crimean-Congo hemorrhagic fever (CCHF) group including HAZV and Crimean-Congo hemorrhagic fever virus (CCHFV) [1,2]. While NSDV

\footnotetext{
* Correspondence: o.flusin@crssa.net

'Unité de virologie, Institut de Recherche Biomédicale des Armées (IRBA), 24 avenue des Maquis du Grésivaudan 38702 La Tronche, France

Full list of author information is available at the end of the article
}

induces acute hemorrhagic gastroenteritis in sheep and goats, CCHFV is responsible of severe hemorrhagic fever in humans associated with elevated levels of mortality (up to 50\%) [1,3]. Due to its high pathogenicity for humans and because of the lack of therapeutics, CCHFV must be handled in BSL4 (biosafety level 4) laboratory [1]. Widely distributed throughout Eastern Europe, Asia and Africa, CCHFV represents a major public health problem $[4,5]$ and is now considered as an emerging disease [6,7]. HAZV was isolated for the first time in 1954 from Ixodes ticks collected in Pakistan [8-10]. Although its natural host is not known, antibodies against HAZV were detected in rodent sera [11]. While non pathogenic for humans, it is lethal in newborn mice [12] and elicits cross-protection against 
CCHFV challenge in adult mice [13]. HAZV represents an alternative model to study CCHFV due to its close serological and phylogenetical relationship [13]. Furthermore, it can be handled in BSL2 laboratories.

The nairovirus are spherical enveloped particles of 100 $\mathrm{nm}$ in diameter. Their genome consists of three segments of single-stranded RNA of negative polarity designated $\mathrm{S}$ (Small), M (Medium) and L (Large) RNA segments. These three segments encode the nucleocapsid protein (NP), the envelope glycoproteins ( $\mathrm{Gn}$ and $\mathrm{Gc}$ ) and an RNA-dependent RNA polymerase (L), respectively $[2,14,15]$. During the viral cycle, NP and L drive the processes of transcription (mRNA synthesis) and replication (synthesis of genomic RNA) that occur in the cytoplasm [2]. Thus, targeting these proteins is likely an accurate strategy to inhibit the viral replication.

Currently, there are neither vaccines nor effective therapies to treat bunyavirus infection in humans. Ribavirin, however, has been shown to inhibit CCHFV replication in Vero cells [16], reducing the mean time to death in infant mice [17] and partially protecting infected STAT-1 KO mice [18]. Several studies reported the efficiency of oral or intravenous use of ribavirin to treat CCHFV infection cases [19-21] but to date, no double-blind trial had been carried out. Therefore, it is important to initiate research programs aimed towards the development of new medical countermeasures against CCHFV.

Since its discovery in 1998 [22], RNA interference (RNAi) has been successfully applied as a technology to inhibit gene expression. Small interfering RNAs (siRNAs), the mediators of RNAi, are a class of doublestranded RNA molecules (20-25 nucleotides in length) that interfere with translation by inducing sequence-specific degradation of homologous mRNA [23,24]. Recently, several RNAi-based applications for gene silencing have been developed to target pathogenic human viruses causing acute or chronic infections including HIV-1 $[25,26]$, influenza virus $[27,28]$, respiratory syncytial virus $[29,30]$, hepatitis B [31-34] and C viruses [35-37], as well as Marburg and Ebola filoviruses [38-40].

In this report, we tested various chemically synthesized siRNAs for their ability to inhibit HAZV replication in cell culture. We demonstrated that siRNAs targeting the NP mRNA depicted a stronger antiviral effect than those designed to inhibit the $L$ and $M$ segment encoded mRNAs. siRNAs were efficient when transfected in cells before or after HAZV infection and their use in combination with ribavirin induced a synergistic or an additive antiviral effect, according to the dose of ribavirin used. Thus, our study highlights the potential of RNAi in the antiviral treatment of nairovirus infection.

\section{Methods}

\section{Cell lines and viruses}

A549 cells (human lung carcinoma cell line, ATCC CCL185 ) and Vero E6 cells (African green monkey kidney, ATCC CRL-1586) were grown in F12K medium and Dulbecco's modified eagle medium DMEM (Gibco, Invitrogen Corporation, Paisley, United Kingdom), respectively, supplemented with $10 \%$ heat-inactivated fetal calf serum (FCS; Invitrogen, Sao Paulo, Brazil) and maintained at $37^{\circ} \mathrm{C}$ in a $5 \% \mathrm{CO}_{2}$ atmosphere. BHK21 cells (baby hamster kidney, ATCC CCL10) were cultured in Glasgow minimum essential medium GMEM (Gibco, Invitrogen Corporation) with $10 \%$ FCS, $10 \%$ tryptose phosphate (Sigma-Aldrich, St Quentin-Fallavier, France) and $50 \mathrm{mM}$ HEPES (Gibco, Invitrogen Corporation) at $37^{\circ} \mathrm{C}$ in a $5 \% \mathrm{CO}_{2}$ atmosphere.

The HAZV strain JC280 used in these experiments was produced by infecting $90 \%$ confluent BHK21 cells at a multiplicity of infection (MOI) of 0.001 . Virus was titrated using a focus-forming assay in Vero E6 cells as described below. Viral stocks usually reached $10^{6}-10^{7}$ foci forming units per $\mathrm{ml}(\mathrm{ffu} / \mathrm{ml})$.

\section{HAZV titration}

Monolayers of Vero E6 cultured in 12-well microplates were infected with serial 10 -fold dilutions of supernatant from infected cells. After $1 \mathrm{hr}$ incubation at $37^{\circ} \mathrm{C}, 3.2 \%$ carboxymethylcellulose (CMC) sodium salt (VWR International Ltd, Poole, England) were added into each well. CMC overlay was removed five days post-infection and cells were fixed with $4 \%$ formaldehyde for $20 \mathrm{~min}$ at room temperature (RT) and permeabilized in $0.5 \%$ Triton X-100 (Sigma-Aldrich, St Quentin-Fallavier, France) for $5 \mathrm{~min}$. Viral foci were detected by probing with mouse anti-HAZV hyperimmune ascitic fluid (1:2000) for $1 \mathrm{hr}$ at $37^{\circ} \mathrm{C}$, followed by horseradish peroxydase-conjugated goat anti-mouse IgG (1:2000, Interchim, Montluçon, France) at $37^{\circ} \mathrm{C}$ for $1 \mathrm{hr}$. The cell monolayer was then incubated with $0.7 \mathrm{mg} / \mathrm{ml}$ of 3,3'-diaminobenzidine (DAB) solution (Sigma-Aldrich, St Quentin-Fallavier, France) diluted in PBS 1X for 10 min at RT. Once clusters of infected cells were visible (dark stain), the reaction was stopped by removing the DAB solution followed by water washing. The foci were counted manually under the light microscope.

\section{Design and synthesis of siRNAs}

The sequences of HAZV L, M and S genomic segments [GenBank:DQ076419.1, DQ813514.1 and M86624.1, respectively] were used to design the siRNAs. Duplexes of 21-nucleotide siRNAs with short 3' overhangs were synthesized by Qiagen (Courtaboeuf, France). For each viral mRNAs, four lyophilized siRNAs were produced 
(Table 1) and their sequence was subjected to a BLAST search against GenBank to minimize off-target effects. In the present study, a non targeting siRNA (siNT) showing no complementarities neither with HAZV mRNAs nor with any human, mouse or rat mRNAs was used as a negative control (Table 1). The TOX siRNA (siTOX) (Dharmacon RNAi technologies, Lafayette, USA) was used to determine transfection efficacy (see below). Before use, all siRNAs were reconstituted in rehydration buffer to obtain $20 \mu \mathrm{M}$ solutions according to the company's instructions.

\section{siRNAs transfection and A549 cells infection with HAZV}

Twenty four hours before transfection, A549 cells were seeded in 24-well microplates at a density of $8 \times 10^{4}$ cells/well to achieve $60 \%$ confluent cell monolayers the day after. Various siRNAs concentrations (ranging from 0.01 to $100 \mathrm{nM}$ ) were complexed with the Lipofectamine 2000 transfection reagent (Invitrogen, Cergy Pontoise, France) in Opti-MEM I medium (Gibco, Invitrogen Corporation, Paisley, United Kingdom). The final volume of Lipofectamine 2000 was $1.5 \mu \mathrm{l} /$ well. The transfection mixture was incubated for $20 \mathrm{~min}$ at RT to allow the formation of siRNA/transfection reagent complexes and $100 \mu \mathrm{l}$ of the solution were added in each well. One day post-transfection, cells were gently washed twice with F12K medium and infected with HAZV at a MOI of 0.1 .
The inoculum was incubated for $1 \mathrm{hr}$. Cells were then cultivated in F12K medium supplemented with $0.4 \%$ FCS for $48 \mathrm{hrs}$. Infected cells supernatants were tittered as described above. The $\mathrm{EC}_{50}$ was calculated as the mean of two independent experiments using the GraphPadPrism version 4.00 software (GraphPad Software, San Diego California, USA) for non linear regression.

For the post infection treatment studies, 60\% confluent A549 cell monolayers were infected with HAZV for $1 \mathrm{hr}$ at a MOI of 0.01 . At $1 \mathrm{hr}, 8 \mathrm{hrs}$ or $24 \mathrm{hrs}$ postinfection, $100 \mu \mathrm{l}$ of the transfection mixture (containing $100 \mathrm{nM}$ of siRNA) were added. One day after transfection, cells were washed, and grown in F12K medium with $0.4 \%$ FCS for $48 \mathrm{hrs}$. The supernatant from infected cells were then harvested and tittered.

For each experiment, transfection efficiency was monitored by transfecting A549 cells with $100 \mathrm{nM}$ of siTOX under the same experimental conditions as described above. Cells successfully transfected with siTOX undergo apoptosis and cell death within 24-48 hrs. After 3 days of incubation, siTOX-transfected cells were trypsinized and manually counted using a hematocytometer (Trypan blue exclusion assay). Transfection efficiency was calculated as the ratio between the number of viable siTOX-transfected cells versus non-transfected cells. In our experiments, transfection efficiency was routinely above $90 \%$.

Table 1 List of siRNAs used in this study

\begin{tabular}{|c|c|c|c|}
\hline siRNA & Targeted genomic region & Sequence of duplex siRNA & GenBank accession number \\
\hline sis1 & 91 to 111 & $\begin{array}{l}\text { Sense 5'-AGAUUGUUGCCAGUACUAAdTdT-3' } \\
\text { Antisense 5'-UUAGUACUGGCAACAAUCUdTdG-3' }\end{array}$ & $\begin{array}{l}\text { S Hazara segment JC280 } \\
\text { [DQ076419.1] }\end{array}$ \\
\hline sis2 & 1321 to 1341 & $\begin{array}{l}\text { Sense 5'-AGGCAGUCCUCAACUAUAAdTdT-3' } \\
\text { Antisense 5'-UUAUAGUUGAGGACUGCCUdTdT-3' }\end{array}$ & \\
\hline sis3 & 641 to 661 & $\begin{array}{c}\text { Sense 5'-CGAUGAUGCGCCAAAGAGAdTdT-3' } \\
\text { Antisense 5'-UCUCUUUGGCGCAUCAUCGdGdA-3' }\end{array}$ & \\
\hline sis4 & 881 to 901 & $\begin{array}{c}\text { Sense 5'-CAAAGACCAAGUCGACCAAdTdT-3' } \\
\text { Antisense 5'-UUGGUCGACUUGGUCUUUGdTdT-3' }\end{array}$ & \\
\hline siM1 & 3260 to 3280 & $\begin{array}{l}\text { Sense 5'-CAGUCAUGAUGGUGGUUUAdTdT-3' } \\
\text { Antisense 5'-UAAACCACCAUCAUGACUGdTdG-3' }\end{array}$ & $\begin{array}{l}\text { M Hazara segment JC280 } \\
\text { [DQ813514.1] }\end{array}$ \\
\hline siM2 & 3929 to 3949 & $\begin{array}{l}\text { Sense 5'-CGAGCAUAAGGGUACAAUAdTdT-3' } \\
\text { Antisense 5'-UAUUGUACCCUUAUGCUCGdAdG-3' }\end{array}$ & \\
\hline $\operatorname{siM3}$ & 1689 to 1709 & $\begin{array}{l}\text { Sense 5'-GAUGAAAGUUGCUCCUAUAdTdT-3' } \\
\text { Antisense 5'-UAUAGGAGCAACUUUCAUCdGdT-3' }\end{array}$ & \\
\hline siM4 & 2924 to 2944 & $\begin{array}{l}\text { Sense 5'-CAAAUACUUUGUCACCAAAdTdT-3' } \\
\text { Antisense 5'-UUUGGUGACAAAGUAUUUGdTdT-3' }\end{array}$ & \\
\hline siL1 & 10545 to 10565 & $\begin{array}{c}\text { Sense 5'-CGAGGAUAAUAUUGGCAAAdTdT-3' } \\
\text { Antisense 5'-UUUGCCAAUAUUAUCCUCGdTdG-3' }\end{array}$ & $\begin{array}{l}\text { L Hazara segment JC280 } \\
\text { [M86624.1] }\end{array}$ \\
\hline sil2 & 9847 to 9867 & $\begin{array}{l}\text { Sense 5'-CGAGGAUAAUAUUGGCAAAdTdT-3' } \\
\text { Antisense 5'-UAAAGUGUUUAUUAUAACCdTdG-3' }\end{array}$ & \\
\hline siL3 & 1408 to 1428 & $\begin{array}{l}\text { Sense 5'-CAGAGAAAUUGCUGAUAUAdTdT-3' } \\
\text { Antisense 5'-UAUAUCAGCAAUUUCUCUGdTdG-3' }\end{array}$ & \\
\hline siL4 & 10323 to 10343 & $\begin{array}{l}\text { Sense 5'-CAGUGAUAAAGGUAAAGAAdTdT-3' } \\
\text { Antisense 5'-UUCUUUACCUUUAUCACUGdGdG-3' }\end{array}$ & \\
\hline \multicolumn{2}{|r|}{ Non targeting siRNA (siNT) } & $\begin{array}{l}\text { Sense 5'-UUCUCCGAACGUGUCACGUdTdT-3' } \\
\text { Antisense 5'-ACGUGACACGUUCGGAGAAdTdT-3' }\end{array}$ & \\
\hline
\end{tabular}




\section{Detection of HAZV nucleoprotein by Western blot}

A549 cells, seeded in 6-well microplates at a density of 3.2 $\times 10^{5}$ cells/well, were transfected with siRNA and infected with HAZV as described above. Protein extraction was performed 48 hrs post-infection as follow: confluent cells were washed twice in fresh phosphate-buffered saline $1 \mathrm{X}$ (PBS 1X) and lysed in buffer containing $20 \mathrm{mM}$ Tris $\mathrm{pH}$ 7.5, $100 \mathrm{mM} \mathrm{NaCl}, 0.6 \%$ NP40, $0.5 \mathrm{mM}$ EDTA and protease inhibitors cocktail (Complete EDTA-free, Roche Diagnostics GmbH, Mannheim, Germany) for $10 \mathrm{~min}$ on ice. After removal of cellular debris by centrifugation at $12,000 \times \mathrm{g}$ for $10 \mathrm{~min}, 20 \mu \mathrm{l}$ of protein extracts were boiled for $5 \mathrm{~min}$ in Laemmli buffer and separated on a $10 \%$ SDS-PAGE. Proteins were then electrotransferred onto a polyvinylidene fluoride (PVDF) membrane (BioRad Laboratories, Marne-la-Coquette, France). The PVDF membrane was saturated with 5\% dry milk in PBS 1X containing $0.1 \%$ Tween-20 and incubated overnight at $4{ }^{\circ} \mathrm{C}$ with mouse anti-HAZV hyperimmune ascitic fluid (1:250) or with mouse anti-GAPDH monoclonal antibody (1:1000, Ambion, Austin, TX, USA). Horseradish peroxydaselabeled goat anti-mouse IgG (1:10000, Interchim, Montluçon, France) was used as secondary antibody followed by chemoluminescent (ECL) revelation (Amersham GE Healthcare, Orsay, France).

\section{ELISA-based assay for interferon- $\beta$ detection}

A549 cells were cultured in 24-well microplates at a density of $8 \times 10^{4}$ cells/well and transfected as previously described with either $100 \mathrm{nM}$ (i.e. $1.48 \mu \mathrm{g} / \mathrm{ml}$ ) of siNT, siS1 and siS2 or $0.25 \mu \mathrm{g} / \mathrm{ml}$ of poly(I:C) dsRNA (SigmaAldrich, St Quentin-Fallavier, France). Cell culture supernatants were harvested $24 \mathrm{hrs}$ post-transfection to detect human beta interferon (IFN- $\beta$ ). The cytokine measurement was performed using a sandwich enzyme-linked immunosorbent assay (ELISA) kit (PBL Biomedical Laboratories Tebu-Bio, Le Perray-en-Yvelines, France), according to the manufacturer's instructions.

\section{Antiviral assays with ribavirin and combination with siS1 or siS2}

Confluent monolayers of A549 cells in 24-well plates were infected with HAZV at a MOI of 0.1. Cells were then cultivated with F12K medium supplemented with $0.4 \%$ FCS or treated with $0.4 \%$ FCS F12K medium containing serial dilutions of ribavirin (1- $\beta$-D-ribofuranosyl1H-1,2,4-triazole-3-carboxamide) (Sigma-Aldrich, St Louis, Missouri, USA). Forty eight hours post-infection, the supernatant of each well was collected and virus titer was performed. The $\mathrm{EC}_{50}$ value for ribavirin was determined as the mean of two independent experiments.

The combination assay required $60 \%$ confluent monolayers of A549 cells in 24-well microplates transfected with siS1, siS2 or siNT at a concentration of $1 \mathrm{nM}$ and
$10 \mathrm{nM}$. One day post-transfection, cells were washed twice, infected with HAZV at a MOI of 0.1. One hour after infection, the inoculum was removed and transfected cells were cultured for 48 hrs in $0.4 \%$ FCS F12K medium containing 0,25 or $50 \mu \mathrm{M}$ of ribavirin. The cell supernatants were then tittered.

\section{Statistical analysis}

In this study, we compared the antiviral effect of selected siRNAs to the negative control (siNT) to detect significant variations using the Student's t-test $(\mathrm{P} \leq 0.05$ was regarded as significant difference between the two groups of transfected/infected cells).

\section{Results}

\section{Inhibition of HAZV replication using segment-specific} siRNAs

To evaluate the inhibitory activity of siRNAs on HAZV replication, twelve siRNAs were designed to target the mRNAs produced by the $\mathrm{L}, \mathrm{M}$, and $\mathrm{S}$ genomic segments (Table 1). We analyzed the inhibitory effect of the $\mathrm{L}, \mathrm{M}$ and S-specific siRNAs. As shown in figure 1A, when used at $100 \mathrm{nM}, \mathrm{siS1}, \mathrm{siS} 2$ and siS3 strongly inhibited virus replication by $87.8 \%, 91.6 \%$ and $86.1 \%$, respectively, compared to siNT control $(\mathrm{p}<0.05)$. In contrast, siS4 did not induce any significant antiviral effect in A549-infected cells. siM1, siM2 and siM3 showed moderate but significant activities on HAZV replication $(38.3 \%, 56.2 \%$ and $29.4 \%$ of inhibition respectively) whereas siM4 did not have any activity (figure 1B). Lastly, siL2, siL3 and siL4 did not inhibit HAZV replication ( $p>0.05)$ while siL1 slightly did ( $33.5 \%$ of inhibition, $\mathrm{p}=0.04$, figure $1 \mathrm{C}$ ).

\section{Inhibition of HAZV replication by siS1 and siS2 in A549 cells}

Since siS1 and siS2 showed the most efficient anti HAZV activity, we decided to further focus on the characterization of these two siRNAs. We first tested their efficacy at $100 \mathrm{nM}$ in cells infected at different multiplicity of infection (i.e. MOI 0.01, 0.1 and 1). Whatever the viral load, a significant inhibition of HAZV replication was observed for both siRNAs when compared to siNT: the inhibition ranged from $83.1 \%$ to $97.1 \%$ for siS1 and from $94.4 \%$ to $98.3 \%$ for siS2 (figure $2 \mathrm{~A}$ ).

Because siRNAs treatment could be cytotoxic and therefore may affect viral growth, we performed a Trypan blue exclusion assay to evaluate cell growth and viability upon siRNA transfection. The morphology of treated cells was examined daily using phase-contrast light microscopy. Three days post siRNA transfections, the cell number per well was determined and compared to non treated cells by manual counting with a hematocytometer. In these experiments, we did not detect any cytotoxic effect of siS1 and siS2 on A549 cells at any concentrations used (not 

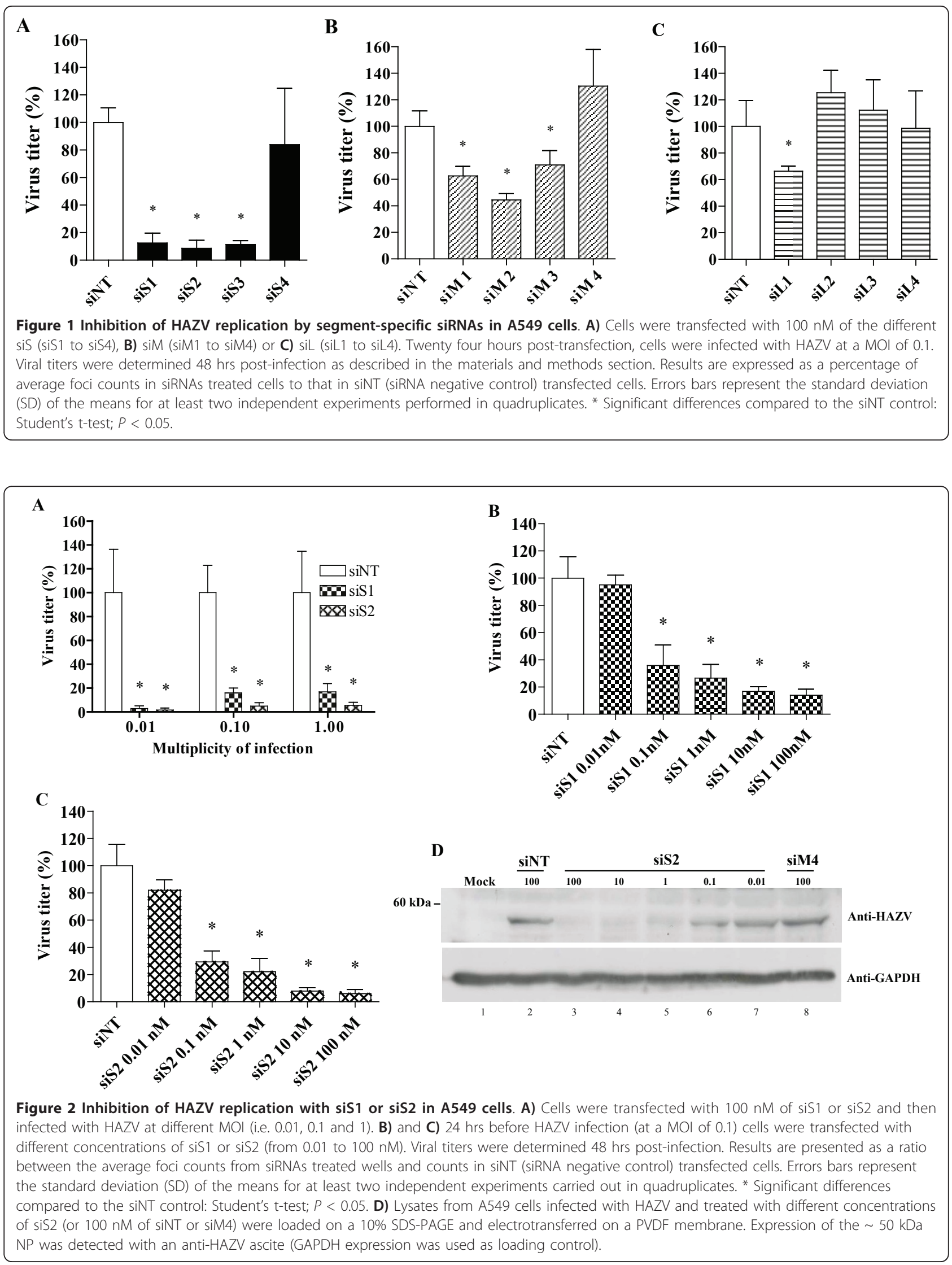
shown). We also investigated whether the IFN pathway could be stimulated in siRNAs transfected cells as reported in earlier studies [41,42]. We found that the siRNAs tested did not induce any IFN $-\beta$ response whereas the poly(I:C) control was a good stimulator (not shown). Thus, HAZV inhibition was siS1 and siS2 specific and was not due to any side effects.

We then examined the antiviral effects of increasing concentrations of siS1 and siS2. A concentration dependent inhibitory activity was observed for both siRNAs when compared to siNT (figures $2 \mathrm{~B}$ and $2 \mathrm{C}$ ). siS1 induced an average inhibition of $64.2 \%$ at $0.1 \mathrm{nM}$ and $86 \%$ at $100 \mathrm{nM}$. The production of infectious HAZV particles was reduced by $70.6 \%$ at $0.1 \mathrm{nM}$ and $94 \%$ at $100 \mathrm{nM}$ when cells were transfected with siS2. No significant viral inhibition was observed at siRNAs concentration of $0.01 \mathrm{nM}$. From these experiments the estimated $50 \%$ effective concentration $\left(E_{50}\right)$ was 0.09 $\mathrm{nM}$ for siS1 and $0.07 \mathrm{nM}$ for siS2. Thus, both siRNAs efficiently inhibited HAZV replication in a concentration dependant manner, in cell culture.

\section{Specific inhibition of NP expression by siS1 and siS2}

Since siS1 and siS2 were designed to target the NP transcript, we wanted to demonstrate that HAZV replication inhibition was associated with NP synthesis reduction. As shown in Figure 2D, when cells were transfected with different concentrations of siS2, a dose-response decrease of NP expression was observed. The $\sim 50 \mathrm{kDa}$ NP was hardly detectable in cells treated with 100, 10 and $1 \mathrm{nM}$ of siS2 (lanes 3, 4 and 5). This was in sharp contrast with the amount of NP seen in siNT transfected-cells (lane 2). When siS2 was used at $0.1 \mathrm{nM}$, NP synthesis was moderately inhibited (lane 6) while no inhibition was observed in cells transfected with $0.01 \mathrm{nM}$ of siS2 (lane 7). As expected, siM4, which did not inhibit HAZV replication (Figure 1B), did not interfere with NP expression (lane 8). A similar siS1 dose response inhibition of NP production was observed (not shown). Thus, the decrease of NP synthesis by siS1 and siS2 completely parallels the HAZV replication inhibition (Figures $2 \mathrm{~B}$ and $2 \mathrm{C}$ ).

\section{Antiviral activities of siS1 and siS2 transfected before and after HAZV infection}

To estimate the stability of siRNA in vitro, we performed a time-course experiment in which A549 cells were infected at $24 \mathrm{hrs}, 48 \mathrm{hrs}$ or $72 \mathrm{hrs}$ after siS1 or siS2 treatment (figure 3A). A significant reduction of HAZV replication was observed when infection occurred $24 \mathrm{hrs}$ post-transfection (80\% with siS1 and $93 \%$ with siS2). Interestingly, the antiviral effect was maintained at least three days post-treatment (up to $80.4 \%$ and $87.4 \%$ inhibition using siS1 and siS2 respectively), indicating the siRNAs stability over this period of time.
We also studied the antiviral effect of siS1 and siS2 transfected at various time post-infection (p-i). As illustrated in figure $3 \mathrm{~B}$, when cells are treated $1 \mathrm{hr}$ or $8 \mathrm{hrs}$ p-i, HAZV titer was reduced by more than $88 \%$. When cell transfection was performed $24 \mathrm{hrs} \mathrm{p}-\mathrm{i}$, a moderate inhibition $>50 \%$ was still observed $(\mathrm{P}<0.05)$. This last experiment indicated that when used at $100 \mathrm{nM}$ both siRNAs exhibited a significant antiviral activity on HAZV that had already been replicating for $24 \mathrm{hrs}$.

\section{Additive or synergistic inhibition of HAZV replication by ribavirin and siS1 or siS2}

As depicted in figure 4A, ribavirin, which is a ribosyl purine analogue, exhibited a clear concentration-dependent anti HAZV activity leading to a complete inhibition at $100 \mu \mathrm{M}$. No cytotoxic effect of ribavirin was observed in the range of concentrations used (data not shown). The ribavirin $\mathrm{EC}_{50}$ was estimated at $8.9 \mu \mathrm{M}$.

Since ribavirin and siRNAs (i.e. siS1 and siS2) have two distinct modes of action and target two different viral components (viral polymerase and mRNA coding for NP, respectively), we wondered whether the combination of ribavirin and siRNAs could induce a higher inhibitory activity than the sum of the individual activities. We performed an assay in which A549 cells were transfected with siS1 or siS2, 24 hrs before being infected with HAZV and then subsequently treated with $25 \mu \mathrm{M}$ of ribavirin. As shown in Figure 4B, when cells were treated with either $1 \mathrm{nM}$ or $10 \mathrm{nM}$ of siS1 in combination with $25 \mu \mathrm{M}$ of ribavirin, a significant synergistic antiviral activity was observed. Similarly, siS2 at $1 \mathrm{nM}$ in association with $25 \mu \mathrm{M}$ of ribavirin reduced the virus titer in a synergistic manner $(\mathrm{P}<$ 0.05) (figure 4C). However, at a concentration of 10 $\mathrm{nM}$, the combination of siS2 with ribavirin only induced an additive effect (figure 4C). In the same way, when ribavirin was used at $50 \mu \mathrm{M}$, an additive antiviral activity was observed with 1 or $10 \mathrm{nM}$ of siS1 or siS2 (data not shown). Thus, these experiments suggest that the combinatorial treatment including ribavirin and NP-targeting siRNAs could represent a strategy to control nairovirus infection.

\section{Discussion}

With the noticeable exception of ribavirin recommended by the World Health Organization (WHO) to treat CCHFV infection [43], there is no specific medical therapy. Therefore, there is a need for the development of novel antiviral strategies against nairovirus infections.

In this work, for the first time, we evaluated the antiviral activity of siRNAs targeting the $\mathrm{L}$ (polymerase), $\mathrm{M}$ (glycoproteins) and $\mathrm{S}$ (nucleoprotein) transcripts of HAZV, a non pathogenic nairovirus in humans, which is considered as a surrogate CCHFV model. 

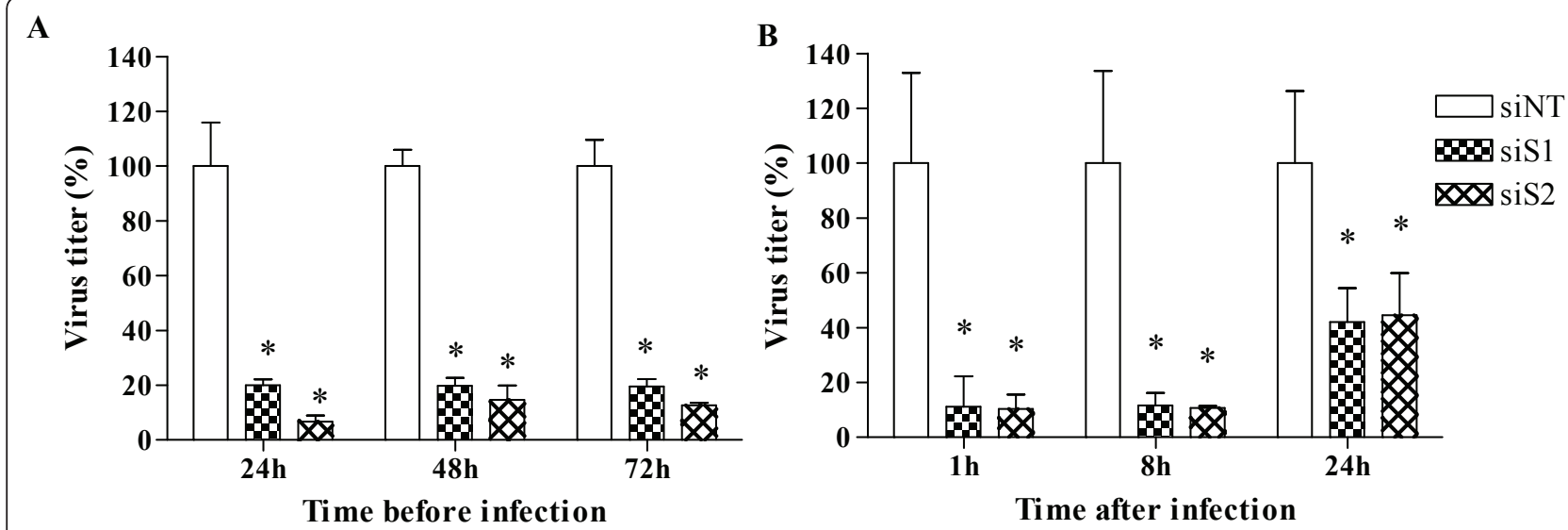

Figure 3 Antiviral activities of siS1 and siS2 transfected before and after HAZV infection. A) A549 cells were transfected with $100 \mathrm{nM}$ of siNT (siRNA negative control), siS1 or siS2, 24 hrs, 48 hrs or 72 hrs before HAZV infection (MOI 0.1). B) Cells were infected with HAZV at a MOI of 0.01 and then transfected with $100 \mathrm{nM}$ of siNT, siS1 or siS2, 1 hr, 8 hrs or 24 hrs post-infection. Viral titers were determined 48 hrs post-infection. Results are shown as a ratio between virus titer obtained in siRNAs treated wells and titer determined in siNT transfected cells. Errors bars represent the standard deviation (SD) of the means for at least two independent experiments done in quadruplicates. ${ }^{*}$ Significant differences compared to the siNT control: Student's t-test; $P<0.05$.

We observed that siRNAs complementary to the mRNAs encoded by the $\mathrm{L}$ and $\mathrm{M}$ genomic segments had a lower effect than those targeting the $\mathrm{S}$ segment. Interestingly, three studies performed in arthropod cells showed that the nucleoprotein gene of orthobunyaviruses is a RNAi prim target. We demonstrated the efficient inhibition of HAZV in tick cells via RNAi induced by a Semliki Forest replicon expressing the $\mathrm{S}$ segment whereas the L segment had no effect [44]. In earlier studies, Billecocq et $a l$. and Powers et al. observed a similar phenomenom in mosquito cells infected by Rift Valley Fever virus [45] and La Crosse virus [46], respectively. Furthermore, in mammalian cells La Crosse virus replication was successfully decreased by siRNAs targeting the $\mathrm{S}$ segment and similarly to our results, the $\mathrm{L}$ and $\mathrm{M}$ siRNAs had a much weaker effect [47]. Finally, orthobunyavirus Akabane replication was inhibited up to $99 \%$ by siRNAs directed against highly conserved regions of the nucleoprotein gene [48].

As other RNA viruses, nairovirus present a high mutation rate which might contribute to their escape from siRNAs inhibition. The emergence of viral mutants is lowered when using siRNAs targeting the most conserved viral sequences. Among the three genomic segments, the $\mathrm{S}$ segment is the most conserved within the Nairovirus genus because of its lowest mutation rate $[49,50]$. This observation indicates that siRNAs directed against the $\mathrm{S}$ segment are potentially interesting antinairovirus molecules.

The nucleoprotein plays a crucial role in the regulation of viral transcription and replication. It associates with genomic RNA and serves as a template for the polymerase to initiate both steps during virus cycle. It is assumed that cytoplasmic NP concentration is important for the transition from transcription to replication [2] and therefore, a decrease in NP production should contribute to virus inhibition, as observed in our study.

Among all tested siRNAs, only three (siS1, siS2 and siS3) exhibited a strong inhibition of HAZV replication (up to 90\%). The unequal siRNAs efficiency is in agreement with previous works [51-53]. The interaction of proteins with the viral transcripts or the presence of secondary structures in these mRNAs may interfere the proper recognition by the homologous siRNAs $[54,55]$, explaining the variability of siRNAs efficacy. Interestingly, the combination of siS1, siS2 and siS3 used at a concentration of $33 \mathrm{nM}$ (100 nM siRNA final concentration) induced $\sim 90 \%$ virus inhibition which is similar to the effect observed for each individual siRNAs (data not shown, figure 1A). The absence of additive or synergistic antiviral effect observed here was also reported in other studies. It was hypothesized that the competition of siRNAs for RISC might explain this lack of effect $[56,57]$.

In our study, the two most active siRNAs, siS1 and siS2, demonstrated a specific inhibitory effect against HAZV in a dose-dependent manner. These two siRNAs did not induce IFN production or cell toxicity. We showed that treatment with each siRNAs correlates with the reduction of nucleoprotein expression level. A concentration as low as $0.1 \mathrm{nM}$ for both siRNAs was sufficient to reduce significantly HAZV replication. A similar antiviral effect at such concentrations had already been described in a previous study with Epstein-Barr virus [58]. We observed that the siRNA stability lasted at least up to $72 \mathrm{hrs}$. The prolonged stability of siRNAs with a relatively long half life (from 3 to 8 days after transfection) was also shown in experiments 


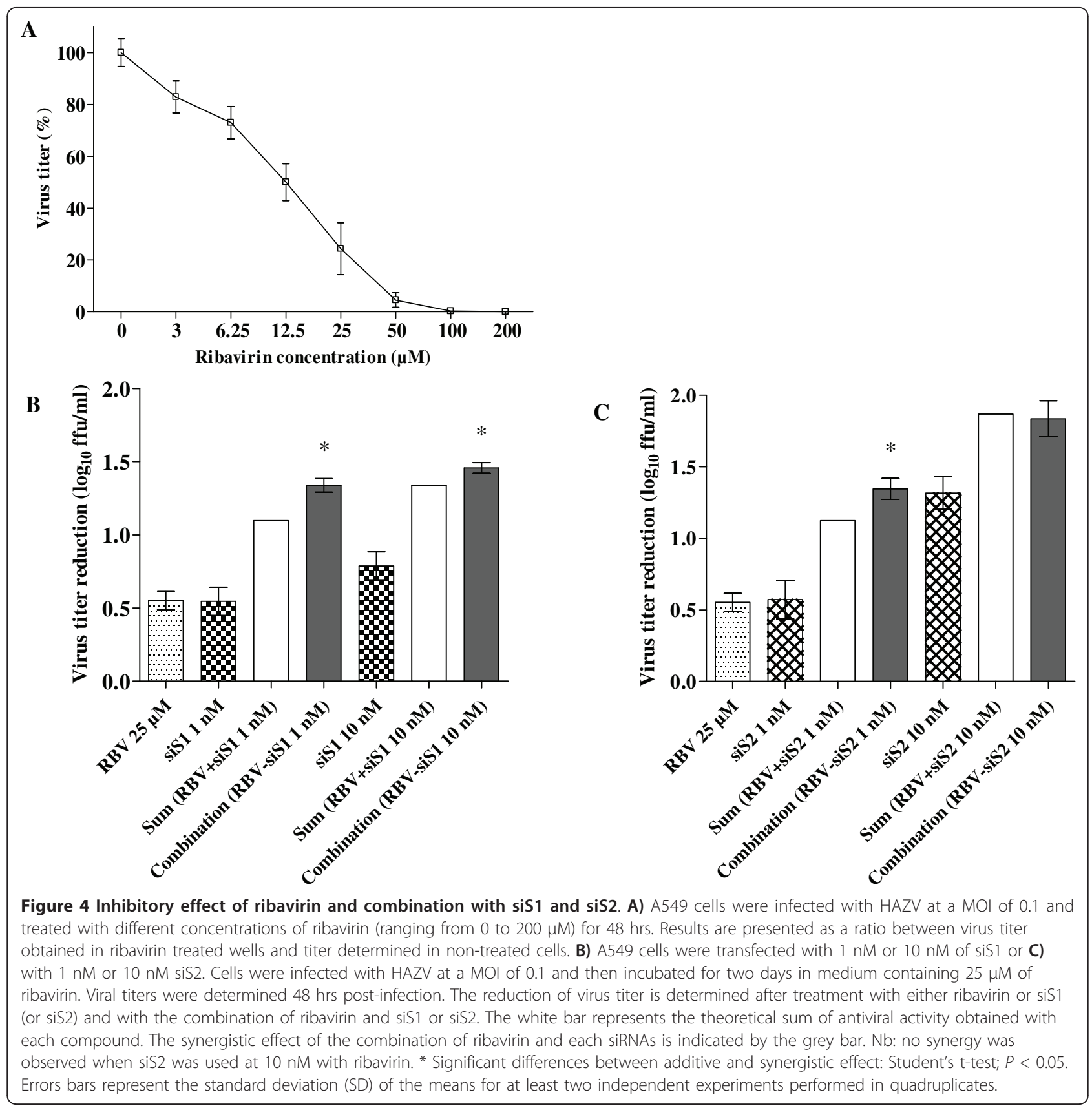

with vaccinia virus [59], monkeypox virus [53], food and mouth disease virus [60] and HIV-1 [61]. We also demonstrated that the antiviral activity of siRNAs was effective when carried out after infection. Taken together, the results are encouraging for the use of siRNA as future prophylactic and therapeutic treatments of nairovirus infection.

Since its discovery [22], RNAi technology has been assessed in several clinical trials. Among these, the most developed assays include the treatment of HIV-1 [62] and RSV [63]. siRNAs were successfully used against viral diseases in numerous animal models including infections affecting the liver: hepatitits $C$ virus $[64,65]$, hepatitits B virus $[31,33,34,66,67]$ or Hepatitis E virus [68]. These data suggest that a similar strategy may be considered to treat patients infected with CCHFV which has an important hepatotropism.

We demonstrated in vitro the inhibitory activity of ribavirin against HAZV in a concentration dependent manner. This guanosine analogue acts through several mechanisms including the replication of viral nucleic acid. Ribavirin and siRNAs having distinct modes of 
action and different target, it was tempting to use them in combination to improve the efficacy of each separate treatment. We reported here the additive or synergistic effect of siRNAs in combination with ribavirin without increasing the cellular toxicity. Our results highlight the interest of a combined therapy. Such a therapy is known to reduce the drug toxicity by decreasing the active dose [69] and preventing the antiviral compound resistance $[70,71]$. Ribavirin is a potent inhibitor of several viruses in vitro [16] and in vivo [18]. Thus, it should be interesting to associate ribavirin and siRNAs to treat CCHFV infections.

\section{Conclusions}

We demonstrated the ability of siRNAs targeting transcripts encoded by $\mathrm{S}$ segment to inhibit Hazara nairovirus replication in mammalian cell cultures. We reported the strong antiviral effect of siRNA and ribavirin in a combined treatment. This promising strategy could be used in a future anti-nairovirus therapy.

\section{List of abbreviations}

HAZV: Hazara virus; CCHFV: Crimean-Congo hemorrhagic fever virus; NSDV: Nairobi sheep disease virus; RNAi: RNA interference; siRNA: small interfering RNA; MOI: multiplicity of infection

\section{Acknowledgements}

We thank Corinne Ducournau and Aurélie Georges for excellent technical assistance and Jeffrey Froude for critical reading of the manuscript. This work was supported by grants from the Service de Santé des Armées, the Direction Générale pour l'Armement and the ARAMI association.

\section{Author details}

'Unité de virologie, Institut de Recherche Biomédicale des Armées (IRBA), 24

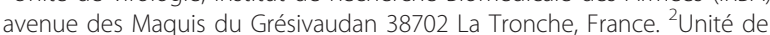
Génétique Moléculaire des Bunyavirus, Institut Pasteur, 25 rue du docteur Roux 75724 Paris cedex 15, France. ${ }^{3}$ Department of Pathology and Immunology, Centre Médical Universitaire, 1 rue Michel Servet 1211 Geneva 4, Switzerland.

\section{Authors' contributions}

$\mathrm{OF}, \mathrm{JMC}$ and $\mathrm{Fl}$ participated in the conception and design of the study. OF performed most of the experiments. FI carried out the immunoblot assay. SV provided reagents and technical help. OF, CNP, MB, JMC and FI contributed to the analysis and interpretation of the data. OF, CNP, MB and FI wrote the paper. All authors read and approved the final manuscript.

\section{Competing interests}

The authors declare that they have no competing interests.

Received: 18 February 2011 Accepted: 21 May 2011

Published: 21 May 2011

\section{References}

1. Whitehouse CA: Crimean-Congo hemorrhagic fever. Antiviral Res 2004, 64:145-160.

2. Schmaljohn CS, Nichol ST: Bunyaviridae: The Viruses and their Replication. In Fields Virology. Volume 2.. Fifth edition. Edited by: Knipe DM HPM, Griffin DE. Philadelphia: Lippincott Williams 2007:1741-1789.

3. Hoogstraal H: The epidemiology of tick-borne Crimean-Congo hemorrhagic fever in Asia, Europe, and Africa. J Med Entomol 1979, 15:307-417.
4. Ergonul O: Crimean-Congo haemorrhagic fever. Lancet Infect Dis 2006, 6:203-214.

5. Flusin $\mathrm{O}$, Iseni F, Rodrigues R, Paranhos-Baccalà G, Crance JM, Marianneau P, Bouloy M, Peyrefitte CN: Crimean-Congo Hemorrhagic fever: basics for general practitioners. Med Trop 2010, 70:429-438.

6. Maltezou HC, Andonova L, Andraghetti R, Bouloy M, Ergonul O, Jongejan F, Kalvatchev N, Nichol S, Niedrig M, Platonov A, Thomson G, Leitmeyer K, Zeller $\mathrm{H}$ : Crimean-Congo hemorrhagic fever in Europe: current situation calls for preparedness. Euro Surveill 2010, 15:19504.

7. Maltezou HC, Papa A: Crimean-Congo hemorrhagic fever: risk for emergence of new endemic foci in Europe? Travel Med Infect Dis 2010, 8:139-143.

8. Begum F, Wisseman CL Jr, Casals J: Tick-borne viruses of West Pakistan. IV. Viruses similar to or identical with, Crimean hemorrhagic fever (Congo-Semunya), Wad Medani and Pak Argas 461 isolated from ticks of the Changa Manga Forest, Lahore District, and of Hunza, Gilgit Agency, W. Pakistan. Am J Epidemiol 1970, 92:197-202.

9. Darwish MA, Imam IZ, Omar FM, Hoogstraal H: Results of a preliminary seroepidemiological survey for Crimean-Congo hemorrhagic fever virus in Egypt. Acta Virol 1978, 22:77.

10. Honig JE, Osborne JC, Nichol ST: The high genetic variation of viruses of the genus Nairovirus reflects the diversity of their predominant tick hosts. Virology 2004, 318:10-16.

11. Darwish MA, Hoogstraal H, Roberts TJ, Ghazi R, Amer T: A seroepidemiological survey for Bunyaviridae and certain other arboviruses in Pakistan. Trans R Soc Trop Med Hyg 1983, 77:446-450.

12. Smirnova SE, Shestopalova NM, Reingold VN, Zubri GL, Chumakov MP: Experimental Hazara Virus infection in mice. Acta Virol 1977, 21:128-132.

13. Foulke RS, Rosato RR, French GR: Structural polypeptides of Hazara virus. J Gen Virol 1981, 53:169-172.

14. Elliott RM, Schmaljohn CS, Collett MS: Bunyaviridae genome structure and gene expression. Curr Top Microbiol Immunol 1991, 169:91-141.

15. Haferkamp S, Fernando L, Schwarz TF, Feldmann H, Flick R: Intracellular localization of Crimean-Congo Hemorrhagic Fever (CCHF) virus glycoproteins. Virol J 2005, 2:42.

16. Watts DM, Ussery MA, Nash D, Peters CJ: Inhibition of Crimean-Congo hemorrhagic fever viral infectivity yields in vitro by ribavirin. Am J Trop Med Hyg 1989, 41:581-585.

17. Tignor GH, Hanham CA: Ribavirin efficacy in an in vivo model of Crimean-Congo hemorrhagic fever virus (CCHF) infection. Antiviral Res 1993, 22:309-325.

18. Bente DA, Alimonti JB, Shieh WJ, Camus G, Stroher U, Zaki S, Jones SM: Pathogenesis and immune response of Crimean-Congo hemorrhagic fever virus in a STAT-1 knockout mouse model. J Virol 2010, 84:11089-11100.

19. Bodur H, Erbay A, Akinci E, Onguru P, Bayazit N, Eren SS, Kubar A: Effect of oral ribavirin treatment on the viral load and disease progression in Crimean-Congo hemorrhagic fever. Int J Infect Dis 2010.

20. Ergonul O: DEBATE (see Elaldi $\mathrm{N}$ et al, Efficacy of oral ribavirin treatment in Crimean-Congo haemorrhagic fever: a quasi-experimental study from Turkey. Journal of Infection 2009; 58: 238-244): Biases and misinterpretation in the assessment of the efficacy of oral ribavirin in the treatment of Crimean-Congo hemorrhagic fever. J Infect 2009, 59:284-286, author reply 286-289.

21. Ergonul O, Celikbas A, Dokuzoguz B, Eren S, Baykam N, Esener H: Ribavirin in crimean-congo hemorrhagic fever: primum non nocere. Clin Infect Dis 2009, 49:1621-1622.

22. Fire A, Xu S, Montgomery MK, Kostas SA, Driver SE, Mello CC: Potent and specific genetic interference by double-stranded RNA in Caenorhabditis elegans. Nature 1998, 391:806-811.

23. Elbashir SM, Lendeckel W, Tuschl T: RNA interference is mediated by 21and 22-nucleotide RNAs. Genes Dev 2001, 15:188-200.

24. Hammond SM: Dicing and slicing: the core machinery of the RNA interference pathway. FEBS Lett 2005, 579:5822-5829.

25. Jacque JM, Triques K, Stevenson M: Modulation of HIV-1 replication by RNA interference. Nature 2002, 418:435-438.

26. Kumar P, Ban HS, Kim SS, Wu H, Pearson T, Greiner DL, Laouar A, Yao J, Haridas V, Habiro K, Yang YG, Jeong JH, Lee KY, Kim YH, Kim SW, Peipp M, Fey GH, Manjunath N, Shultz LD, Lee SK, Shankar P: T cell-specific siRNA delivery suppresses HIV-1 infection in humanized mice. Cell 2008, 134:577-586. 
27. Ge Q, Filip L, Bai A, Nguyen T, Eisen HN, Chen J: Inhibition of influenza virus production in virus-infected mice by RNA interference. Proc Natl Acad Sci USA 2004, 101:8676-8681.

28. Tompkins SM, Lo CY, Tumpey TM, Epstein SL: Protection against lethal influenza virus challenge by RNA interference in vivo. Proc Natl Acad Sci USA 2004, 101:8682-8686.

29. Bitko V, Musiyenko A, Shulyayeva O, Barik S: Inhibition of respiratory viruses by nasally administered siRNA. Nat Med 2005, 11:50-55.

30. DeVincenzo J, Cehelsky JE, Alvarez R, Elbashir S, Harborth J, Toudjarska I, Nechev L, Murugaiah V, Van Vliet A, Vaishnaw AK, Meyers R: Evaluation of the safety, tolerability and pharmacokinetics of ALN-RSV01, a novel RNAi antiviral therapeutic directed against respiratory syncytial virus (RSV). Antiviral Res 2008, 77:225-231.

31. Giladi H, Ketzinel-Gilad M, Rivkin L, Felig Y, Nussbaum O, Galun E: Small interfering RNA inhibits hepatitis $B$ virus replication in mice. Mol Ther 2003, 8:769-776.

32. Hamasaki K, Nakao K, Matsumoto K, Ichikawa T, Ishikawa H, Eguchi K: Short interfering RNA-directed inhibition of hepatitis $B$ virus replication. FEBS Lett 2003, 543:51-54.

33. McCaffrey AP, Nakai H, Pandey K, Huang Z, Salazar FH, Xu H, Wieland SF, Marion PL, Kay MA: Inhibition of hepatitis $B$ virus in mice by RNA interference. Nat Biotechnol 2003, 21:639-644.

34. Ying RS, Zhu C, Fan XG, Li N, Tian XF, Liu HB, Zhang BX: Hepatitis B virus is inhibited by RNA interference in cell culture and in mice. Antiviral Res 2007, 73:24-30.

35. Kapadia SB, Brideau-Andersen A, Chisari FV: Interference of hepatitis C virus RNA replication by short interfering RNAs. Proc Natl Acad Sci USA 2003, 100:2014-2018.

36. Seo MY, Abrignani $S$, Houghton M, Han JH: Small interfering RNAmediated inhibition of hepatitis $C$ virus replication in the human hepatoma cell line Huh-7. J Virol 2003, 77:810-812.

37. Khaliq S, Jahan S, Ijaz B, Ahmad W, Asad S, Pervaiz A, Samreen B, Khan M, Hassan S: Inhibition of core gene of HCV 3a genotype using synthetic and vector derived siRNAs. Virol J 2010, 7:318.

38. Fowler T, Bamberg S, Moller P, Klenk HD, Meyer TF, Becker S, Rudel T: Inhibition of Marburg virus protein expression and viral release by RNA interference. J Gen Virol 2005, 86:1181-1188.

39. Geisbert TW, Hensley LE, Kagan E, Yu EZ, Geisbert JB, Daddario-DiCaprio K, Fritz EA, Jahrling PB, McClintock K, Phelps JR, Lee AC, Judge A, Jeffs LB, MacLachlan I: Postexposure protection of guinea pigs against a lethal ebola virus challenge is conferred by RNA interference. J Infect Dis 2006, 193:1650-1657.

40. Geisbert TW, Lee AC, Robbins M, Geisbert JB, Honko AN, Sood V, Johnson JC, de Jong S, Tavakoli I, Judge A, Hensley LE, Maclachlan I: Postexposure protection of non-human primates against a lethal Ebola virus challenge with RNA interference: a proof-of-concept study. Lancet 2010, 375:1896-1905.

41. Judge AD, Sood V, Shaw JR, Fang D, McClintock K, MacLachlan I: Sequence-dependent stimulation of the mammalian innate immune response by synthetic siRNA. Nat Biotechnol 2005, 23:457-462.

42. Sledz CA, Holko M, de Veer MJ, Silverman RH, Williams BR: Activation of the interferon system by short-interfering RNAs. Nat Cell Biol 2003, 5:834-839.

43. Ergonul O: Treatment of Crimean-Congo hemorrhagic fever. Antiviral Res 2008, 78:125-131.

44. Garcia S, Billecocq A, Crance JM, Munderloh U, Garin D, Bouloy M: Nairovirus RNA sequences expressed by a Semliki Forest virus replicon induce RNA interference in tick cells. J Virol 2005, 79:8942-8947.

45. Billecocq A, Vazeille-Falcoz M, Rodhain F, Bouloy M: Pathogen-specific resistance to Rift Valley fever virus infection is induced in mosquito cells by expression of the recombinant nucleoprotein but not NSs nonstructural protein sequences. J Gen Virol 2000, 81:2161-2166.

46. Powers AM, Kamrud KI, Olson KE, Higgs S, Carlson JO, Beaty BJ: Molecularly engineered resistance to California serogroup virus replication in mosquito cells and mosquitoes. Proc Natl Acad Sci USA 1996, 93:4187-4191.

47. Soldan SS, Plassmeyer ML, Matukonis MK, Gonzalez-Scarano F: La Crosse virus nonstructural protein NSs counteracts the effects of short interfering RNA. J Virol 2005, 79:234-244.

48. Levin A, Kutznetova L, Kahana R, Rubinstein-Guini M, Stram Y: Highly effective inhibition of Akabane virus replication by siRNA genes. Virus Res 2006, 120:121-127.
49. Anagnostou V, Papa A: Evolution of Crimean-Congo Hemorrhagic Fever virus. Infect Genet Evol 2009, 9:948-954.

50. Deyde VM, Khristova ML, Rollin PE, Ksiazek TG, Nichol ST: Crimean-Congo hemorrhagic fever virus genomics and global diversity. J Virol 2006, 80:8834-8842.

51. Saijo M, Tang Q, Shimayi B, Han L, Zhang Y, Asiguma M, Tianshu D, Maeda A, Kurane I, Morikawa S: Antigen-capture enzyme-linked immunosorbent assay for the diagnosis of crimean-congo hemorrhagic fever using a novel monoclonal antibody. J Med Virol 2005, 77:83-88.

52. Vigne S, Germi R, Duraffour S, Larrat S, Andrei G, Snoeck R, Garin D, Crance JM: Specific inhibition of orthopoxvirus replication by a small interfering RNA targeting the D5R gene. Antivir Ther 2008, 13:357-368.

53. Alkhalil A, Strand S, Mucker E, Huggins JW, Jahrling PB, Ibrahim SM: Inhibition of monkeypox virus replication by RNA interference. Virol J 2009, 6:188.

54. Haasnoot PC, Cupac D, Berkhout B: Inhibition of virus replication by RNA interference. J Biomed Sci 2003, 10:607-616.

55. Oliveira S, Storm G, Schiffelers RM: Targeted delivery of siRNA. J Biomed Biotechnol 2006, 2006:63675.

56. Castanotto D, Sakurai K, Lingeman R, Li H, Shively L, Aagaard L, Soifer H, Gatignol A, Riggs A, Rossi Jj: Combinatorial delivery of small interfering RNAs reduces RNAi efficacy by selective incorporation into RISC. Nucleic Acids Res 2007, 35:5154-5164.

57. Koller E, Propp S, Murray H, Lima W, Bhat B, Prakash TP, Allerson CR, Swayze EE, Marcusson EG, Dean NM: Competition for RISC binding predicts in vitro potency of siRNA. Nucleic Acids Res 2006, 34:4467-4476.

58. Larrat S, Morand P, Bas A, Vigne S, Crance JM, Boyer V, Nicod S, Grossi L, Buisson M, Burmeister WP, Seigneurin JM, Germi R: Inhibition of EpsteinBarr virus replication by small interfering RNA targeting the Epstein-Barr virus protease gene. Antivir Ther 2009, 14:655-662.

59. Vigne S, Duraffour S, Andrei G, Snoeck R, Garin D, Crance JM: Inhibition of vaccinia virus replication by two small interfering RNAs targeting B1R and G7L genes and their synergistic combination with cidofovir. Antimicrob Agents Chemother 2009, 53:2579-2588.

60. Bayry J, Tough DF: Is RNA interference feasible for the control of footand-mouth disease outbreaks? Trends Immunol 2005, 26:238-239, discussion 239-241.

61. Song E, Lee SK, Dykxhoorn DM, Novina C, Zhang D, Crawford K, Cerny J, Sharp PA, Lieberman J, Manjunath N, Shankar P: Sustained small interfering RNA-mediated human immunodeficiency virus type 1 inhibition in primary macrophages. J Virol 2003, 77:7174-7181.

62. DiGiusto DL, Krishnan A, Li L, Li H, Li S, Rao A, Mi S, Yam P, Stinson S, Kalos M, Alvarnas J, Lacey SF, Yee JK, Li M, Couture L, Hsu D, Forman SJ, Rossi JJ, Zaia JA: RNA-based gene therapy for HIV with lentiviral vectormodified CD34(+) cells in patients undergoing transplantation for AIDSrelated lymphoma. Sci Transl Med 2010, 2:36ra43.

63. DeVincenzo J, Lambkin-Williams R, Wilkinson T, Cehelsky J, Nochur $\mathrm{S}$, Walsh E, Meyers R, Gollob J, Vaishnaw A: A randomized, double-blind, placebo-controlled study of an RNAi-based therapy directed against respiratory syncytial virus. Proc Natl Acad Sci USA 2010, 107:8800-8805.

64. Watanabe T, Umehara T, Kohara M: Therapeutic application of RNA interference for hepatitis C virus. Adv Drug Deliv Rev 2007, 59:1263-1276.

65. Sakamoto N, Tanabe Y, Yokota T, Satoh K, Sekine-Osajima Y, Nakagawa M, Itsui Y, Tasaka M, Sakurai Y, Cheng-Hsin C, Yano M, Ohkoshi S, Aoyagi Y, Maekawa S, Enomoto N, Kohara M, Watanabe M: Inhibition of hepatitis C virus infection and expression in vitro and in vivo by recombinant adenovirus expressing short hairpin RNA. J Gastroenterol Hepatol 2008, 23:1437-1447.

66. Morrissey DV, Blanchard K, Shaw L, Jensen K, Lockridge JA, Dickinson B, McSwiggen JA, Vargeese C, Bowman K, Shaffer CS, Polisky BA, Zinnen S: Activity of stabilized short interfering RNA in a mouse model of hepatitis B virus replication. Hepatology 2005, 41:1349-1356.

67. Morrissey DV, Lockridge JA, Shaw L, Blanchard K, Jensen K, Breen W, Hartsough K, Machemer L, Radka S, Jadhav V, Vaish N, Zinnen S, Vargeese C, Bowman K, Shaffer CS, Jeffs LB, Judge A, MacLachlan I, Polisky B: Potent and persistent in vivo anti-HBV activity of chemically modified siRNAs. Nat Biotechnol 2005, 23:1002-1007.

68. Huang F, Hua X, Yang S, Yuan C, Zhang W: Effective inhibition of hepatitis E virus replication in $\mathrm{A} 549$ cells and piglets by RNA interference (RNAi) targeting RNA-dependent RNA polymerase. Antiviral Res 2009, 83:274-281. 
69. Quenelle DC, Prichard MN, Keith KA, Hruby DE, Jordan R, Painter GR,

Robertson A, Kern ER: Synergistic efficacy of the combination of ST-246 with CMX001 against orthopoxviruses. Antimicrob Agents Chemother 2007, 51:4118-4124.

70. Nakata H, Steinberg SM, Koh Y, Maeda K, Takaoka Y, Tamamura H, Fujii N, Mitsuya H: Potent synergistic anti-human immunodeficiency virus (HIV) effects using combinations of the CCR5 inhibitor aplaviroc with other anti-HIV drugs. Antimicrob Agents Chemother 2008, 52:2111-2119.

71. Schopman NC, ter Brake O, Berkhout B: Anticipating and blocking HIV-1 escape by second generation antiviral shRNAs. Retrovirology 2010, 7:52.

doi:10.1186/1743-422X-8-249

Cite this article as: Flusin et al: Inhibition of Hazara nairovirus replication by small interfering RNAs and their combination with ribavirin. Virology Journal 2011 8:249.

Submit your next manuscript to BioMed Central and take full advantage of:

- Convenient online submission

- Thorough peer review

- No space constraints or color figure charges

- Immediate publication on acceptance

- Inclusion in PubMed, CAS, Scopus and Google Scholar

- Research which is freely available for redistribution

Submit your manuscript at www.biomedcentral.com/submit 